\title{
The Implementation of Change Management in Madrasa (Islamic School) Through Compliance of National Standards of Education: Learn from The Australia Education Partnership with Indonesia 2012-2016
}

\author{
Abdul Hadi, Universitas Islam Negeri Raden Fatah Palembang, abd.hadhy@radenfatah.ac.id \\ Kiki Mikail, Universitas Islam Negeri Raden Fatah Palembang, kikimikail_uin@radenfatah.ac.id
}

\begin{abstract}
The Australian Government worked in partnership with developing countries in order to plan and implement aid programs, including humanitarian response actions. Australia-Indonesia bilateral relations helped people's lives by increasing economic growth through infrastructure and better economic governance, improving health and education levels, protecting the poor and vulnerable from shocks, supporting democracy, justice and good governance. This article discussed the development of madrasa (Islamic School) in Indonesia which had received grants from the Australia Education Partnership with Indonesia (AEPI) in 2012-2016. Sources and data processing came from observations and interviews with madrasa (Islamic School) stakeholders who had been the object of program assistance. Seeing the results of observations and studies that had been done, there were many positive impacts that developed in madrasa. One of them was the implementation of change management with the madrasa (Islamic School) management continuously increasing its standards according to the National Education Standards by meeting the national accreditation assessment points.
\end{abstract}

Keywords: islamic school, AEPI, change management

Received: 02.11.2020 Accepted: 17.12.2020 $\quad$ Published: 10.01.2021

\section{INTRODUCTION}

In terms of Indonesian government policies in order to improve the quality of education in Indonesia that Indonesia and Australia had agreed to strengthen cooperation in education with various programs including the Australian Development Scholarships (ADS) program, LAPIS (Learning Assistance Program for Islamic Schools), the Australia Indonesia Basic Education Program (AIBEP), Professional Development for Education Personnel Program (ProDEP), and Sister School Programs, Bridge Projects, and the Australia Education Partnership with Indonesia (AEPI) (Hadi, 2016). Cooperation was intended as a series of relationships that were not based on violence or coercion and legalized. The state leadership established cooperative relations through an international organization and international regime, which was defined as a set of agreed rules, regulations, norms, and decision-making procedures, where the expectations of the leaders and interests of the country meet within a scope of international relations (Dougherty \& Pfaltzgraff, 1997; Dunne, Hansen, \& Wight, 2013; Lawson, 2015).

According to Jacqui de Lacy, on the official website of AusAID, assistance in the education sector was a priority program of AusAID. Through these funds Australia was committed to building more than 2000 schools, especially Islamic schools and Islamic boarding schools. According to him, the construction of Islamic schools was important because many Islamic schools targeted poor communities, especially for girls. In addition to building Islamic schools, this program also aimed to improve the quality of education in Islamic schools through assistance in increasing school accreditation and training for management and school principals in Islamic schools. According to Jamhari Ma'ruf, the aid program for the construction of Islamic schools by Australia was very useful because it answered 5 fundamental problems experienced by the majority of Islamic schools in Indonesia: poor infrastructure, low human resources, traditional school management, narrow insight and financial limitations. This collaboration also succeeded in changing the image and perception of the Indonesian people to be more positive towards Australia. They considered Australia as a friendly and supportive neighboring country (Said, 2015).

This Australian assistance program for Indonesia aimed to support Australia's national interests by helping Indonesia reduce poverty and achieve sustainable development. Programs offered by AusAID were in the fields of: Education and Scholarship, health, climate change, government, policy and coordination 52, gender, reduction, disaster risk, infrastructure, rural productivity, decentralization and poverty alleviation (Hilman, 2013). 
Australia supported Indonesia's commitment to provide access to quality education for all children. Australian assistance varied from basic education to vocational skills training and improving tertiary level qualifications. The assistance was the construction of Australian schools that had built more than 2,000 junior high schools in various regions in Indonesia to help improve access to education. More than 130,000 children were now registered and studying in these schools, 50 percent of these children were girls. Because many schools were built in remote and poor areas, around 70 percent of students can now walk less than three kilometers to school. Absenteeism and dropout rates in these schools were also lower than the national average (Report, 2006).

One of the pre-AEPI assistance programs focused on developing madrasa (Islamic School) quality was LAPIS. The Learning Assistance Program for Islamic School (LAPIS) (P. Crawford, 2010) concept was prepared in May 2004 following instructions by Australia then the Foreign Minister for AusAID to be involved in the Islamic education sub sector (LAPIS, 2010). LAPIS important figures involved in improving the quality of madrasa (Islamic School) in Indonesia include; Mr. Robert Kingham, Firdaus Basuni, Masjkuri Abdillah, Abdul Munir, Mokhammad Ikhsan, Bia Puspita, Abdul Munir and others. The next program was AEPI, which was present as a program that aimed to contribute to improving the quality of basic education in madrasa (Islamic School) in Indonesia. Strengthen systems, institutions and groups that had an impact on benefiting madrasa (Islamic School) children. This goal was achieved through three stages: 1) To increase the capacity of educational empowerment institutions to be able to provide quality education services at the basis of the Islamic education sub-sector; 2) To increase the capacity of madrasa (Islamic School) to manage and implement quality education; and 3) To increase the capacity of local madrasa (Islamic School) community networks.

\section{LITERATURE REVIEW}

Change management can be understood as a process to make something different and towards better directions. The definition of change management can be understood as a structured approach to help organizations and people to transition slowly but surely from the present state to the desired state. Another definition of change management is described as a process, tool and technique for managing the change process on the individual side in order to achieve the required results and realize change effectively through change agents, groups and systems more broadly (Lunenburg, 2010; Marsh, 2004; Pettigrew \& Whipp, 1993).

Changes on a very broad scale were stated by Toffler who stated that change had happened where the first wave of change was the agricultural revolution, followed by the second wave of the industrial revolution. In understanding the symptoms of change, there are various views on how the change occurred, there are those who see change as a process, there are those who view it in stages, there are those who see it with a system approach, and there are those who propose it as a model (Mizani, 2020; Netreba, Bilyk, Oliiar, Martsikhiv, \& Stoliarchuk, 2020; Toffler, 1980).

The concept of social change contains another dimension, namely determinants, direction, actors, and the form of change itself. In this regard, the theory of social change is known from a linear perspective or cyclical perspective. This group, like the figure of Ibn Khaldun, can be categorized as adherents of the cyclical perspective as adopted by Pareto, Sorokin, and Toynbee. While the linear perspective, adopted by Spencer, Comte, Hobhouse, and Mark (Soekanto, 1996). In the case of organizational change according to Burnes that organizational change can be seen as a product of three stages of the process of organizational change that are interdependent, including (1) The choice process, which is related to the nature, scope and focus of decision making, (2) The trajectory process, relating to the organization's past and future direction and it looks like a result of the vision, intentions and goals of the future, (3) The change process, includes an approach to the mechanism to achieve, and produce change (Burnes, 2000; L. Crawford \& Nahmias, 2010; Luecke, 2003; Mabey, Mayon-White, \& Mayon-White, 1993).

Likewise, if human habits and organizational culture are not changed, organizational change will not succeed. Relation to changes made by the Australia Indonesia Education Partnership (AEPI) both structural and cultural aspects must be changed together. Because when there is a change in strategy as a result of changing organizational goals, it will affect the organizational structure and system because the old organizational structure and system is no longer compatible with the new organizational environment. Likewise, aspects of human resources and organizational culture must be changed so that changes in organizational strategy, structure and systems can be implemented (Bannet, Crawford, \& Riches, 1992).

Some understanding of change management that is implemented by AEPI is, first, partnerships related to cooperation between countries namely Australia and Indonesia can be understood as international cooperation where this condition is a norm as a result of interdependent relations and increasingly complex human life in the international community. Basically, cooperation between countries 
carried out by two or more countries is to meet their respective needs and achieve their interests. Cooperation is a form of interaction that arises when there are two people or groups, or countries that work together to achieve one or several goals. Equal international cooperation is mentioned in the term "partnerships". Second, the concept of change in education concerns various aspects of human resources, management, environment, and institutions. All aspects of it experience changes as global developments. For this reason, if an organization or institution is required to make positive changes in order to accelerate management governance and its sustainability conditions in order to continue to exist and be useful.

\section{METHODS}

This article was analyzed using the content analysis approach to the report on the results of the accompanying AEPI activities. Important notes and recommendations in it were then strengthened by sample observations of madrasa (Islamic School) that were targeted by the AEPI program in the South Sumatra region. Note the aspect of change raised as a research question was "what are the lessons of changes found after the implementation of the AEPI program in madrasa. The continuity and change approach was used to make structure of the research. Meanwhile, to explain the contents of the structure in principle, it used the education approach as a system. Therefore, this article was in principle a social research in the field of education by using the principle that the reality of education was very closely related to the social reality that occurred, as well as interacting by taking certain forms which later produced to their respective characteristics.

\section{RESULTS AND DISCUSSION}

The empowerment model implemented by AEPI can encourage accelerated change in madrasa (Islamic School). Based on data obtained that 8 National Education Standards: content standards, processes, competence of graduates, educators and education staff, infrastructure, management, financing, and assessment can be improved in madrasa (Islamic School). The fact shows that the level of success is significant with the change in status from non-accredited to accredited, and all KPAI target madrasa (Islamic School) are accredited. These changes indicate an increase in 8 (eight) education standards in madrasa (Islamic School) (Hadi, 2016).

The flow of the process of change in madrasa (Islamic School) through KPAI from the calculation of the time takes place in a period of 18 months. While from the aspect of the program implementation process; begins with Madrasa (Islamic School) Self Evaluation (EDM), the results are followed up through ESI (Effective School) training, KTSP (Curriculum Based Learning), MBM (Madrasa Based Management), Healthy Madrasa (Islamic School), Active Learning, Innovative, Creative, Effective and Fun (PAIKEM). Library Management, Financial Administration. After all training is completed, mentoring is carried out to ensure the madrasa (Islamic School) implements what is learned during the training. To support the light infrastructure facilities and the cost of the impact of the training the madrassas (Islamic School) were given block grants as a stimulant and audited by the SNIP and AusAID. During the activity monitoring was also carried out, both by the Ministry of Religion and AusAID. After the mentoring process, it is continued with the submission of accreditation to the Provincial Accreditation Board (BAP) to get an assessment according to the National Education Standards (Hadi, 2016).

Based on data collection on the lessons of change, the researcher followed up on the FGD notes document carried out by the KPAI where questions were asked about access to planned and unplanned changes resulting from AEPI partnership cooperation with madrasa. The following is the FGD document on positive changes that were not expected or planned due to the cooperation of AEPI partnerships with madrassas in Indonesia. There are conclusions of some notes that are presented through the following points:

1. Changes to time management in madrasa (Islamic School), driven by learning strategies training activities with a focus on timeliness in training.

2. Block grant Financial Management (BG) encourages the growth of characters and attitudes of accountability and transparency using funds that are tightened to change the madrasa mindset of financial spending that is truly what it is.

3. Support for madrasa (Islamic School) increases, because madrasa (Islamic School) are open and transparent making many parties want to help madrasa have plans for madrasa (Islamic School) development; madrasa publicize the planning and use of funds openly, thereby making the community believe; madrasa (Islamic School) information disclosure to the public; the agitation and supervision of the mentor to the madrasa to obtain accredited status makes the community believe in the madrasa (Islamic School). Upstream madrasa (Islamic School) conducts socialization, accountability and transparency. 
4. Increased stakeholder involvement and responsibility in improving the quality of madrasa (Islamic School). Through AEPI the implementation of training, mentoring, and management of madrasa (Islamic School) quality improvement involves many parties, whereas previously it was only hit and run.

5. Madrasa (Islamic School) achievement increases through the motto "madrasa (Islamic School) better and better madrasa (Islamic School)" helped by the School System and Quality (SSQ) model (training, mentoring, and grants). Teachers from other madrasa (Islamic School) raise awareness about the importance of improving the quality of madrasa (Islamic School) and learning for students. In addition, awareness of quality madrassas (Islamic School) is disseminated unintentionally to other non-targeted madrasa.

6. Madrasa (Islamic School) confidence increases. Thanks to the training and assistance from the madrasa (Islamic School) understanding partnership program the National Education Standards are increasing.

7. Bequeath the concept of quality madrasa (Islamic School). Based on the evaluation that in the target areas of AEPI assistance, the madrasa (Islamic School) reached the level of passing the accreditation according to national education standards, which shows the success of this program. In addition, the concept of AEPI with the School System and Quality (SSQ) model (training, mentoring, and grants) is now adopted in 2020 through the Realizing Education's Promise program: Support to Indonesia's Ministry of Religious Affairs for Improved Quality of Education (Madrasa Education Quality Reform) . This project is a Madrasa (Islamic School) Education Quality Reform project sourced from foreign loans (World Bank) implemented by the Directorate General of Islamic Education Ministry of Religion as the Executing Agency.

The implementation of grant assistance, training and mentoring involving all stakeholders at the madrasa (Islamic School) and ministry level has caused a change in mindset about the need for involvement of all stakeholders in madrasa (Islamic School) management and the importance of cooperation and networking in improving the quality of madrasa (Islamic School). Aside from the positive impacts, the AEPI program also had a negative impact. Based on the FGD notes, several points were obtained about the form and causes of the emergence of negative signals to the KPAI program to increase madrasa (Islamic School) capacity. The partnership program only touches madrassas (Islamic School) with certain criteria; Assumptions about nothing legal protection which legalized local governments to help madrassas (Islamic School) (political will and regulation of assistance to madrassas (Islamic School) are still controversial).

Changes in madrasa (Islamic School) are the result of accreditation when the education partnership program ends. The change in madrasa (Islamic School) status from not accredited to accredited shows that madrasa (Islamic School) are recognized as quality educational institutions according to national standards.

\section{CONCLUSIONS}

AEPI with its program was an alternative to encourage the improvement of madrasa education capacity. The assistance provided was an alternative model of assistance for educational institutions considering that so far the government tended to help educational institutions with a hit and run approach without any post-training follow-up or assistance. The assistance program focused on three simultaneous activities in the form of training/workshops; block grant funding; and mentoring can be one of the new approaches to be implemented for educational institutions that were still categorized as lagging behind and need touch and assistance to increase their capacity. In principle, AEPI had the courage from the aspect of "failure risk" in this activity because the target of assistance was a private educational institution that cannot be fully controlled by the government as a state education institution. In addition, this program was not intended to help "Muslims" but rather to improve the quality of education in Indonesia.

\section{REFERENCES}

Bannet, N., Crawford, M., \& Riches, C. (1992). Managing in Education: Individual and Organization Perspectives. London: Paul Chapman Publising Co.

Burnes, B. (2000). Managing Change. Essex-England: Person Education.

Crawford, L., \& Nahmias, A. H. (2010). Competencies for managing change. International journal of project management, 28(4), 405-412.

Crawford, P. (2010). Learning Assistance Program for Islamic Schools (LAPIS) independent completion report. Prepared by Cardno Emerging Markets Pty Ltd for AusAID. 
Dougherty, J. E., \& Pfaltzgraff, R. L. (1997). Jr. James E Dougherty, and Robert L. Pfaltzgraff, JrContending Theories of International Relations. New York: Longman.

Dunne, T., Hansen, L., \& Wight, C. (2013). The end of International Relations theory? European Journal of International Relations, 19(3), 405-425.

Hadi, A. (2016). Tradisi Dan Perubahan Madrasah Di Sumatera Selatan Melalui Program Kemitraan Pendidikan Australia Dengan Indonesia. Jakarta.

Hilman, A. (2013). Hubungan Australia dan Indonesia. Jakarta: Djambatan.

LAPIS. (2010). Independent Completion Report. Diambil dari https://www.dfat.gov.au/aboutus/publications/Pages/learning-assistance-program-for-islamic-schools-lapis-independentcompletion-report

Lawson, S. (2015). Theories of international relations: Contending approaches to world politics. John Wiley \& Sons.

Luecke, R. (2003). Managing change and transition (Vol. 3). Harvard Business Press.

Lunenburg, F. C. (2010). Managing change: The role of the change agent. International journal of management, business, and administration, 13(1), 1-6.

Mabey, C., Mayon-White, B., \& Mayon-White, W. M. (1993). Managing change. Sage.

Marsh, R. P. J. La. (2004). Managing Change for Success. London: Ducan Baird Publisher.

Mizani, H. (2020). The Social Cultural Education in The Qur'an Perspective. Nazhruna: Jurnal Pendidikan Islam, 3(2), 221-231.

Netreba, M., Bilyk, V., Oliiar, M., Martsikhiv, K., \& Stoliarchuk, L. (2020). Educational Issues in the Development of Postmodernism: a Retrospective Review and Current Trends. Postmodern Openings, 11(2 Supl 1), 288-300.

Pettigrew, A., \& Whipp, R. (1993). Managing change for competitive success. Wiley-Blackwell.

Report, E. F. A. G. monitoring. (2006). Literacy for life. New York.

Said, N. (2015). Pelaksanaan Manajemen Sekolah Berbasis Pesantren di Madrasah Tsanawiyah Pesantren Satu Atap Nurul Amal Kenteng Kecamatan Bandungan Kabupaten Semarang. Salatiga: IAIN Salatiga.

Soekanto, S. (1996). Pengantar Sosiologi. Jakarta: Rajawali Pers.

Toffler, A. (1980). The Third Wave. New York: William Morrow and Company Inc. 